\title{
La déportation de Louise Michel. Vérités et légendes de Joël Dauphiné
}

Isabelle Leblic

\section{(2) OpenEdition \\ 1 Journals}

Édition électronique

URL : http://journals.openedition.org/jso/2262

DOI : $10.4000 /$ jso.2262

ISSN : $1760-7256$

Éditeur

Société des océanistes

\section{Édition imprimée}

Date de publication : 15 décembre 2008

Pagination : 355-356

ISBN : 978-2-85430-012-3

ISSN : 0300-953x

Référence électronique

Isabelle Leblic, "La déportation de Louise Michel. Vérités et légendes de Joël Dauphiné », Journal de la Société des Océanistes [En ligne], 126-127 | Année 2008, mis en ligne le 01 décembre 2008, consulté le 24 septembre 2020. URL : http://journals.openedition.org/jso/2262 ; DOI : https://doi.org/10.4000/jso. 2262

Ce document a été généré automatiquement le 24 septembre 2020.

(C) Tous droits réservés 


\title{
La déportation de Louise Michel. Vérités et légendes de Joël Dauphiné
}

\author{
Isabelle Leblic
}

\section{RÉFÉRENCE}

Joël Dauphiné, La déportation de Louise Michel. Vérités et légendes, Paris, les Indes savantes, 152 p., bibliogr., annexes, 6 ill. noir et blanc.

1 Joël Dauphiné, agrégé d'histoire et spécialiste de la Nouvelle-Calédonie où il a résidé et enseigné pendant plus de vingt ans, signe ici son neuvième ouvrage consacré à l'histoire de la colonisation de ce territoire. S'il est des mythes en ce pays, celui de la «bonne Louise", la «Vierge rouge» en est un, qui s'est développé suite à sa déportation - et à celles de nombre de Communards - en Nouvelle-Calédonie de 1873 à 1880.

2 Après une introduction, l'ouvrage comporte cinq parties (Le grand voyage, pp. 9-24 ; l'installation à la presqu'île Ducos, pp. 25-42; le séjour à Numbi, pp. 43-58; Louise à la baie de l'ouest, pp. 59-78; Nouméa, dernière étape de l'exil, pp. 79-100) qui s'attachent «à restituer le récit le plus fidèle et le plus complet possible du long séjour de Louise aux antipodes en vérifiant également l'exactitude et la pertinence des livres qu'elle a écrits ou qui lui sont attribués » (p. 8), suivies d'une conclusion, d'une bibliographie et de documents en annexe. Le but de l'auteur, comme il est indiqué dans le sous-titre de l'ouvrage, est de se débarrasser des erreurs ou demi-vérités qui entourent ce personnage, ses actes et sa personnalité, qui en opacifient la perception, afin de «retrouver l'authenticité d'une femme simple et exceptionnelle à la fois » (p. 8), en démêlant les mensonges et les vérités autour du moment important de son itinéraire personnel et politique constitué par sa déportation en Nouvelle-Calédonie.

Sans entrer dans le détail de cette étude très fouillée, qui reprend pas à pas son voyage et les conditions de son séjour en Nouvelle-Calédonie, nous ne pouvons qu'en recommander la lecture à toute personne intéressée par l'histoire de la colonisation en 
Nouvelle-Calédonie comme de celle de la Commune de Paris... Il nous permet d'avoir un autre regard sur cette femme célèbre, de mieux la connaître, notamment pour la partie calédonienne de sa vie, en passant du mythe à la réalité historique. Comme toutes les études précédentes de l'auteur, celle-ci est très documentée et d'une grande rigueur et elle nous permet d'agrandir encore un peu notre connaissance du pays.

\section{AUTEURS}

\section{ISABELLE LEBLIC}

CNRS - LACITO à Villejuif 